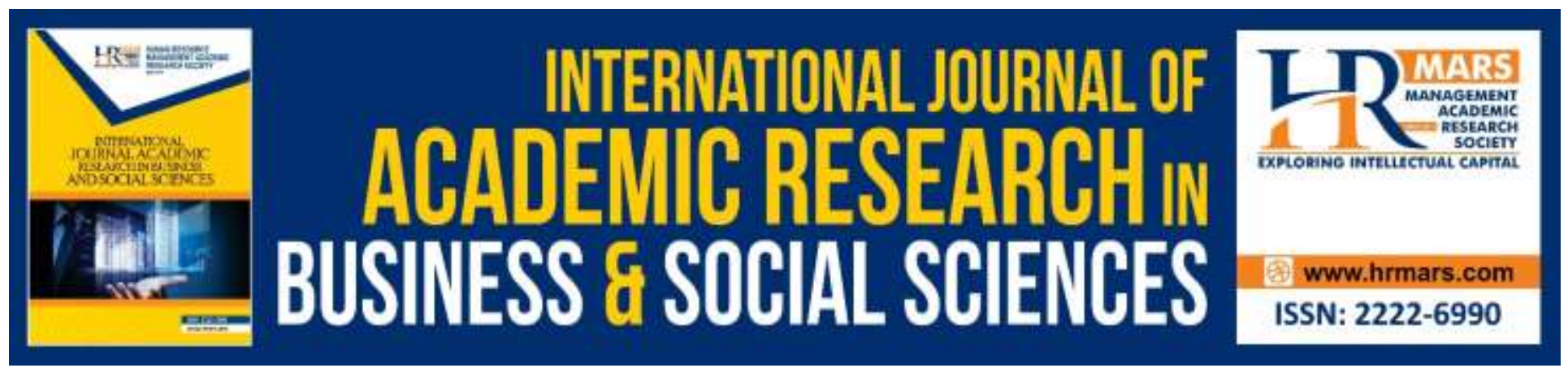

\title{
Regional Economic Integration and Income Inequality in Selected ASEAN Countries
}

\section{Tan Ger Ean, Shazali Bin Abu Mansor, Shirly Wong Siew Ling}

To Link this Article: http://dx.doi.org/10.6007/IJARBSS/v10-i2/6955

DOI:10.6007/IJARBSS/v10-i2/6955

Received: 17 January 2020, Revised: 01 February 2020, Accepted: 12 February 2020

Published Online: 29 February 2020

In-Text Citation: (Ean et al., 2020)

To Cite this Article: Ean, T. G., Mansor, S. B. A., \& Ling, S. W. S. (2020). Regional Economic Integration and Income Inequality in Selected Asean Countries. International Journal of Academic Research in Business and Social Sciences, 10(2), 648-664.

Copyright: (C) 2020 The Author(s)

Published by Human Resource Management Academic Research Society (www.hrmars.com)

This article is published under the Creative Commons Attribution (CC BY 4.0) license. Anyone may reproduce, distribute, translate and create derivative works of this article (for both commercial and non-commercial purposes), subject to full attribution to the original publication and authors. The full terms of this license may be seen

at: http://creativecommons.org/licences/by/4.0/legalcode

Vol. 10, No. 2, 2020, Pg. 648 - 664

http://hrmars.com/index.php/pages/detail/IJARBSS

JOURNAL HOMEPAGE

Full Terms \& Conditions of access and use can be found at http://hrmars.com/index.php/pages/detail/publication-ethics 


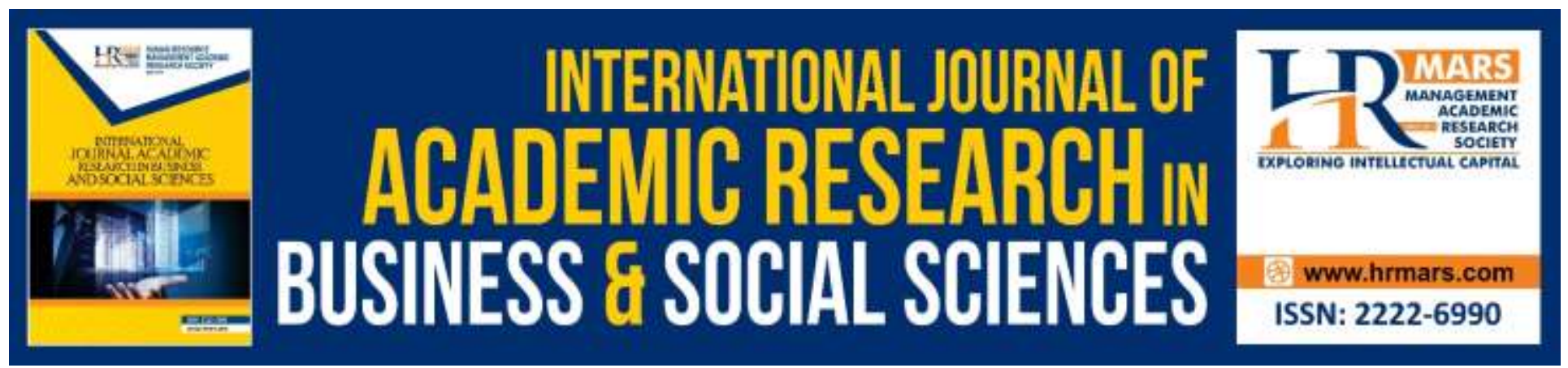

\title{
Regional Economic Integration and Income Inequality in Selected ASEAN Countries
}

\author{
Tan Ger Ean, Shazali Bin Abu Mansor, Shirly Wong Siew Ling \\ University Malaysia Sarawak
}

\begin{abstract}
Widening income inequality in recent years has triggered an outpouring analysis and reflection on the causes of inequality. Economic cooperation demonstrated robust economic growth, reducing poverty but also accompanied by rising inequality. The income gap persists between ASEAN-5 (Indonesia, Malaysia, the Philippines, Singapore, Thailand) and the ASEAN-3 (Cambodia, Laos, Vietnam) has become a prominent issue and policy debate. Hence, this study aims to investigate the relationship of regional economic integration and income inequality by adopting a balanced panel analysis for selected ASEAN countries from 2005 to 2018. Trade and financial integration was evaluated to investigate the influence on inequality. Empirical findings showed that trade integration is more effective than financial integration in improving income distribution. Export activities from the manufacturing and service sectors help ASEAN-5, while the agricultural and manufacturing sectors help ASEAN-3 in narrowing income distribution. Therefore, integration policies to improve inequality should not be universally implied on countries with diverse economics structures and varied development activities.
\end{abstract}

Keywords: Regional Economic Integration, Income Inequality, ASEAN-5, ASEAN-3

\section{Introduction}

Regional integration is creating tremendous opportunities and simultaneously resulting in rising inequality. Regional integration can be conceptualized as the increasing density of international market exchange and development of international political institutions within geographically bounded, politically negotiated and historically specific transnational regions (Macdonald, Marshall \& Pinto, 2012). Of many regional integration blocs that have formed with various goals, the European Union (EU) and the North American while the Association of Southeast Asia Nations (ASEAN) is a good example of a regional integration scheme (Teh, 2004). The region is poised to maintain its strong and steady economic progress with 2018 growth rates averaging 5.3\% according to forecasts by the Asian Development Bank (ADB) (Gnanasagaran, 2018). 
INTERNATIONAL JOURNAL OF ACADEMIC RESEARCH IN BUSINESS AND SOCIAL SCIENCES Vol. 10, No. 2, Feb, 2020, E-ISSN: 2222-6990 @ 2020 HRMARS

Economic collaborations have continued to expand from predominantly trade to skilled manpower and investment flows to address developmental gaps. Accumulations of foreign direct investment (FDI) inflows has been a force driving the intensification of intra-regional trade in Southeast Asia, as well as multiple engines of economic growth. Multinational firms have extended their activities throughout Asian by the means of FDI, have played an important role in development of intraregional production and procurement networks and the vertical economic integration. Less developed countries could take advantage of regional market access opportunities that optimally deploy the region's natural resources, human mobility and technological exchange to help converge the region's different levels of economic development among countries (Asian Development Bank $[A D B], 2018)$. However, inequality remained stubbornly high due to the lack of required skills and inability to access finances hindered the lower socioeconomic levels from reaping the benefits and opportunities of integration (Mordecai, 2017).

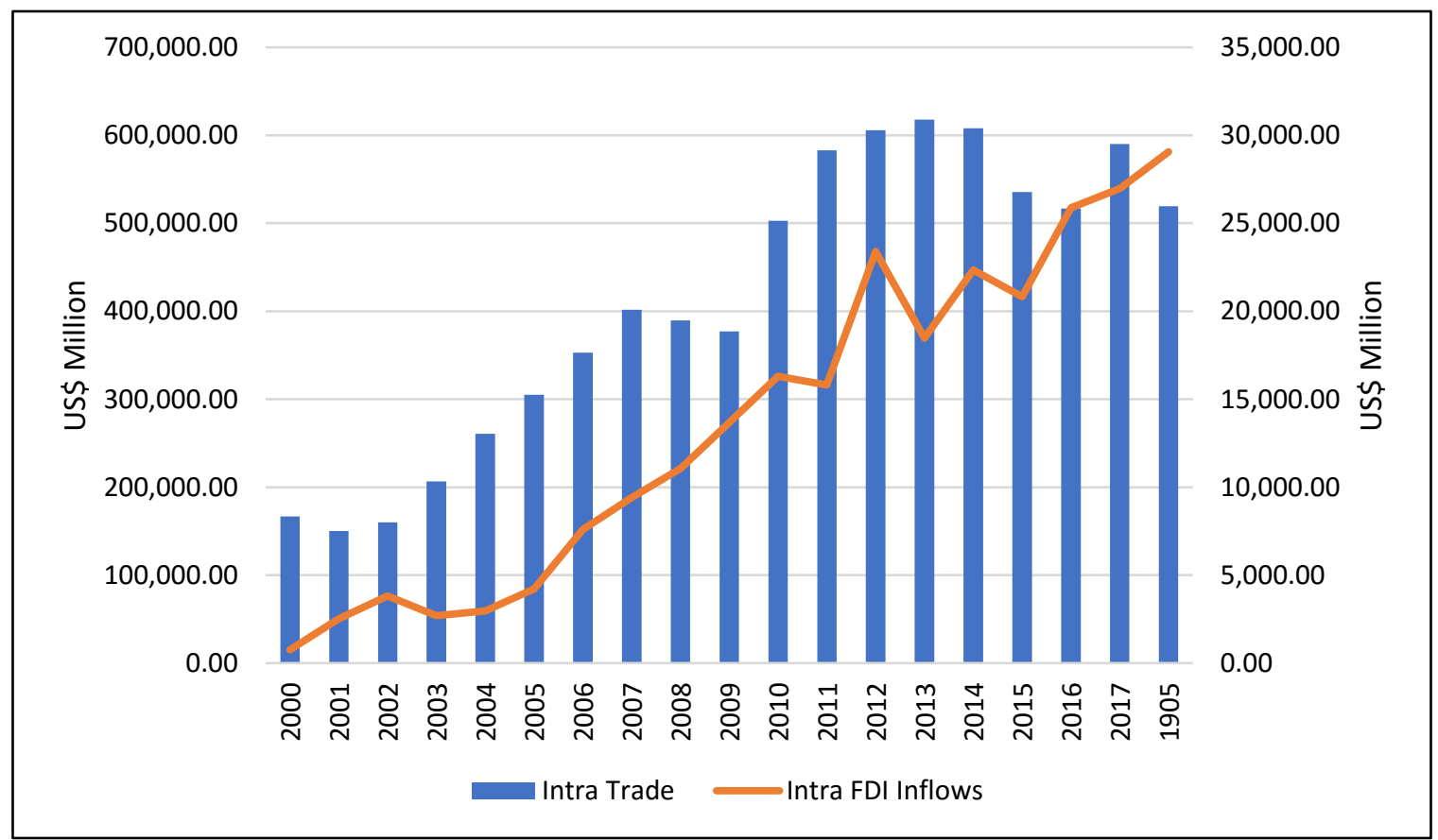

Figure 1.1: ASEAN Intra-Trade and Intra-Foreign Direct Investment Inflows from 2000 to 2018

Source: ASEAN Yearbook (2018)

Based on Figure 1.1, intra-regional trade has risen from 18\% in 2000 to 23\% in 2018. However, economic connections within the region have not deepened as ASEAN regionalization was still heavily dependence on countries outside of ASEAN for the trading of goods, services, investment and technology (Delios, 2017; Ando \& Kimura, 2013). ASEAN is the fourth largest exporting region in the world and has established sophisticated manufacturing capabilities through industrialization and diversified its exports, enabling progress in poverty reduction. Malaysia and Thailand are leading exporters of electrical and electronic products, machinery and automotive parts. The biotech industry in Singapore is growing, and manufactured goods are clustered around chemicals and biomedical 
INTERNATIONAL JOURNAL OF ACADEMIC RESEARCH IN BUSINESS AND SOCIAL SCIENCES Vol. 10, No. 2, Feb, 2020, E-ISSN: 2222-6990 @ 2020 HRMARS

sciences, logistics and transport engineering. Vietnam's top export commodities are broadcasting equipment, telephones and integrated circuits. While other ASEAN countries have assembled export industries running around natural resources. Brunei's primary exports include petroleum gas, crude oil and natural gas. Indonesia is the world's largest producer and exporter of mineral fuels and palm oil, and a leading exporter of animal and vegetable fats. Myanmar is just at the beginning to embark on an unprecedented opening up of its economy, with the garment industry is a major hub job creator. In addition to exporting manufactured and agricultural products, the Philippines is establishing a thriving business-process-outsourcing industry (Vinayak, Thompson \& Tonby, 2014).

ASEAN has taken a step towards financial integration through increased in foreign direct investment inflows over the past two decades, as illustrated in Figure 1.1. Sustained inflows of investments have helped to enhance efficiency, allocate resources more effectively and yielded greater economic prosperity through inclusive economic expansion (Ibrahim, 2015). Financial resources are free to move across the borders, generating opportunities for investment and trade (Hew, 2006). This phenomenon is driven by unilateral reforms created by the "flying geese" phenomena of transferring capital and production to neighbouring countries with a lower cost and further promotes exportoriented industries within the country (Krumm \& Kharas, 2004). Multinational firms and companies with huge investment capital in ASEAN play an essential role in facilitating the rise of intra-ASEAN investments. These capital influxes from the regional market help domestic market expansion, establish production linkages and subsidiary networks, and participation in the regional value chain.

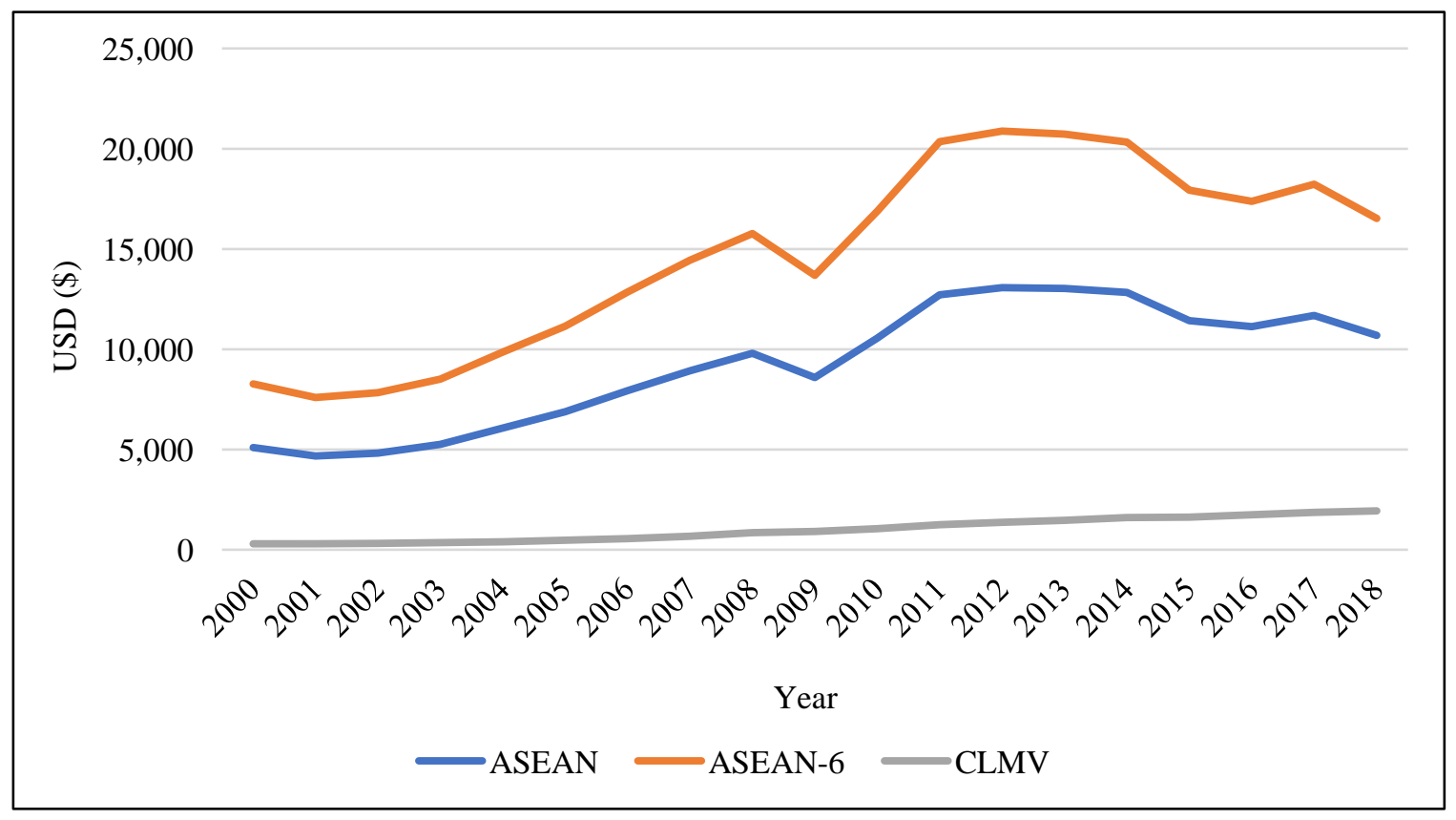

Figure 1.2: Average of GDP Per Capita, 2000-2018 (Current US\$)

Source: World Bank (2019) 
Despite the progressive growth in GDP per capita, variations in GDP per capita are strikingly vast and large disparities persist between the countries. Based on Figure 1.2, the economic gap became extremely stark when compared to the GDP per capita of CLMV countries against ASEAN-6. The creation of two-tiered structure within the region is an obstacle to achieving inclusive and prosperous ASEAN (Sovachana, 2013). In 2018, Singapore emerged as a dominating country among ASEAN, with a per capita GDP of greater than the total of per capita GDP of the rest of the ASEAN members in 2018. This fact indicates the imbalanced among ASEAN economies, with Singapore, oil-rich Brunei, developing states and those poorer nations that are still in the early stages of development, CLMV nations (Mordecai, 2017). The level of disparity is huge and among the individual members, it is extremely high in comparison. Singapore's per capita GDP is 44 times higher than the poorest country in the region, Myanmar, 40 times that of Cambodia, and more than 20 times that of Vietnam. The average for the CLMV was only $10 \%$ of ASEAN-6 (Figure 1.2).

The distribution gap has been declining through several initiatives and projects. However, it has been observed that national elites have captured more of the wealth, meaning that the incomes of the rich have increased more swiftly compared to the incomes of the poor (Hartley, 2017). Thus, regional integration facilitates or dampens inequality within the ASEAN economies are a concern to many economists and academicians. This paper aims to investigate the relationship between regional integration and the influence on income inequality in selected ASEAN countries over the past decades. The study also intends to provide a better understanding on how regional integration can influence the economic performance of developing countries and provide additional insights towards the implementation of regional integration under several objectives.

\section{Theories and Literature Review}

The theoretical foundation of trade integration on domestic income inequality was based on the Heckscher-Ohlin (HO) model and the Stopler-Samuelson (SS) theorem. Heckscher-Ohlin (HO) model on the factor endowments as the basis of trade was based on the Ricardian model of comparative advantage. Each country produced goods depending on their factor of endowments, either labour intensive or capital intensive. Once country participated in international trade, profit-seeking firms will export goods and penetrate their products into a foreign market at a higher price. Subsequently, country will import goods that are scarce in resources or unable to produce (Cornia, 2011). StolperSamuelson believed that the opening of trade will raise income of country with abundant resources. Likewise, countries with abundant supply of labour were expected to experience a decline in domestic inequality. Hence, the neoclassical framework based on the Heckscher-Ohlin-Samuelson (HOS) was established to analyse the consequences of international trade on employment and income distribution (Stolper \& Samuelson, 1941; Samuelson, 1948).

HOS emphasized the increase in return to the country's abundant factor through trade expansion. As the relative price of goods produced increased, the real return of factor used more intensively during the production increased simultaneously. ASEAN integration through the removal of trade barriers allowed countries to specialize in producing commodities that they have a comparative advantage leading to specialization and a greater volume of production. The Factor Price Equalization theorem 
INTERNATIONAL JOURNAL OF ACADEMIC RESEARCH IN BUSINESS AND SOCIAL SCIENCES Vol. 10, No. 2, Feb, 2020, E-ISSN: 2222-6990 @ 2020 HRMARS

stated that under international immobility of factors, ASEAN countries that participated in international trade improve welfare, income and change the income distribution across countries through exporting products that are towards labour intensive and import products that are skill and capital-intensive from foreign countries (Meschi \& Vivarelli, 2009). Developing countries such as CLMV were able to export agriculture, textiles and garments and manufacturing goods that will raise the demand for unskilled labour in the production factor. Hence, wages in the export sector will increase as the export rise and conversely wages in the import sector will fall, leading to an overall decrease in wage dispersion (Roser \& Cuaresma, 2016).

Majority of the regional integration studies earlier focused on the European process as the most developed model of regional integration, but the results have been inconclusive. Auguste (2012) found that the decreased in dispersion of the Gini coefficient in EU between 1980 to 2007 was driven by economic and political integration. Lim and McNelis (2013) showed that trade openness has a larger influence on inequality compared to foreign direct investment or foreign aid provided in 42 low and middle-income countries. Pham (2014) adopted the augmented gravity model and found that the Asia Pacific region supports the creation effect of intra-regional exports within countries with the same development level in reducing within-country inequality. Siddiqui and Zaheer (2017) evaluated the economic progress of Pakistan that was associated with the country opening up their markets for international trade during the last 20 decades. Furuoka et al. (2018) adopted the Kalman filter method-based state space model (SSM) method and found that income convergence exists between Malaysia and Indonesia while the remaining countries remained inconclusive. Contrary, Salman and Javed (2011) found that an increased in import penetration ratio in Pakistan leads to significant deterioration of income inequality of skilled labour compared to that of other skill-based labour. Raychaudhuri and De (2016) carried out a cross country dynamic panel analysis on 14 Asian countries showed that openness leads to unequal distribution of income. Results from Mahesh (2016) based on BRIC countries, Zakaria and Fida (2016) on China and the South Asian Association for Regional Cooperation (SAARC) and Tee et al. (2017) showed that an increased in volume of trade has worsened the distribution.

Several studies depicted economic integration based on the initial development and conditions within the country. Barro (2000), Calderón and Chong (2001), Milanonvic (2002), Milanovic (2005), Gourdon, Maystre and De Melo (2007) and Yenipazarli and Kucukkaya (2016) found that the influence of trade openness on the country varies depending on its initial income level. The developing countries that depended on the primary exports were most likely to experience an increased in inequality while developed countries with manufacturing exports are associated with narrowing inequality. Hence, trade integration involving poor economies would widen distribution in countries with a high population of labour force with little education but contributed towards a reduction in regional disparity among the richer countries. However, Kuo and Lee (2017) found the opposite for developing countries and advanced countries. Economic integration in developing countries help to facilitate economic growth and further contributed to decreasing inequality. However, inequality in advanced countries will only be reduced if the growth rate declines which does not support the Kuznets inverted-U curve. 
On the other hand, Mugeni (2015) found that the FDI inflows alleviate inequality in 153 developed and developing countries from 1995 to 2010. Chen (2016) also found that FDI has directly contributed a decline in rural-urban inequality in China. Trinh (2016) found that FDI improved the distribution of income in Vietnm at the province level from 2002 to 2012. Ucal, While Haug and Bilgin (2016) adopted the nonlinear auto-regressive distributed lag (NARDL) on Turkey from 1970 to 2008. The findings postulated statistically significant and negative impact of FDI on income distribution in the short- and long-run. Conversely, Chintrakarn, Herzer and Nunnenkamp (2011) analyse the long-run impact of inward FDI on income inequality in Latin America from 1980 to 2000 but found that inwards FDI contributed to widen of income gaps in majority of the countries except for Uruguay. Similar findings were also found by Herzer, Hühne and Nunnenkamp (2014) among households in different samples of Latin America. Asteriou, Dimelis and Moudatsou (2014) investigated the inequality based on trade and financial variables across 27 countries in the EU over the period 1995 to 2009. Empirical results suggested that financial globalization through FDI, capital account openness and stock market capitalization has been a contributing factor towards widening of inequality within the countries. The highest contribution stems from FDI. Suanes (2016) based on the sample from Latin American showed that manufacturing and servicing sector worsen income inequality within the country from 1980 to 2009.

Figini and Görg (2011) found that the impact of FDI varies according to the level of development based on 100 developed and developing countries. FDI improve inequality in developed countries but developing countries following the inverted $U$ curve by widening inequality at the early stage but diminishes with further increase in FDI. Similarly, Baek and Shi (2016) studied the influence of financial integration across 26 developed and 52 developing countries from 1990 to 2010. Deepening of financial integration reduce income inequality in developed countries but the oppose for developing countries. Developing countries would deteriorate with an imprudent dependence on a rapid opening up of their financial markets to foreign investors. Chen, Zhao and Zhou (2017) also found that the effects of FDI on China's inequality from 1999 to 2007 following the inverted U curve. Likewise, Mihaylova (2015) found that FDI has the potential reduce income inequality in Central and Eastern Europe (CEE) between 1990 to 2012. However, the ability of the host country to reap the benefits from the FDI depends largely on the level of education and economic development within the country.

\section{Data Methodology}

This study empirically evaluates the influence of regional economic integration towards income inequality across selected ASEAN countries using panel analysis regression. We examines how much of the rise in inequality seen within the region can be attributed to increase in trade and financial openness using annual data from 2005 to 2018 due to availability of data. This study employs the panel cointegration, fully modified ordinary least squares and panel Granger causality Wald test. This study also further evaluates the same variables for the samples ASEAN-8, ASEAN-5 and ASEAN-3. The core objective is to empirically analyse which influencing factors drive inequality across the region. We were also interested to observe the influence of trade and financial openness across the different sample. The data are obtained from the World Development Indicators (WDI), Standardized World 
INTERNATIONAL JOURNAL OF ACADEMIC RESEARCH IN BUSINESS AND SOCIAL SCIENCES Vol. 10, No. 2, Feb, 2020, E-ISSN: 2222-6990 @ 2020 HRMARS

Income Inequality Database (SWIID) and CEIC in order to measure the influence of imposed integration on the income inequality of a country.

Following previous studies to capture the influence of trade integration, trade is represented by three measures of trade integration: trade openness, intra- export and intra-import. Trade openness is the most commonly used variable to assess trade integration in other studies (Furuoka et al., 2018; Selvarajan \& Ab-Rahim, 2017; Tee et al., 2017; Ametoglo \& Guo, 2016; Mahesh, 2016; Yenipazarli \& Kucukkaya, 2016; Zakaria \& Fida, 2016; Lee \& McNelis, 2014; Jaumotte et al., 2013). To further examine the impact of export on reducing inequality, intra-export is split by sector of originagriculture, manufacturing and services. Specifically, financial integration is measured by three indicators, which are financial openness, inflow and outflow of foreign direct investment as a share of GDP. Financial openness indicator is proxied by the Chinn and Ito's (2006) KAOPEN indicator, which reflects a capital account control indicators constructed based on IMF's Annual Report on Exchange Arrangements and Exchange Restriction (AREAER). The financial integration explanatory variables are standard measures that are widely used in previous studies (Furceri et al., 2018; Selvarajan \& AbRahim, 2017; Chen, 2016; Mugeni, 2015; Jaumotte et al., 2013; Chintrakarn et al., 2011). The analysis also includes a number of control variables important in determining how inequality has changed the countries in recent years. These include domestic financial development, measured by the ratio of private credit to GDP, access to education, measured by average years of education, and inflation rate measured by consumer price index.

Table 1: Variable Definition and Data Source

\begin{tabular}{|c|c|c|}
\hline Variables & Definition & Source \\
\hline \multicolumn{3}{|c|}{ Dependent Variables } \\
\hline GINI & Gini coefficient, disposable & SWIID \\
\hline \multicolumn{3}{|c|}{ Independent Variables } \\
\hline TO & Trade Openness (\% of GDP) & CEIC \\
\hline EX & Exports to ASEAN (\% of total exports) & CEIC \\
\hline AGR & $\begin{array}{l}\text { Exports of agriculture products to ASEAN } \\
\text { (\% of total exports) }\end{array}$ & CEIC \\
\hline MANU & $\begin{array}{l}\text { Exports of manufacturing products to } \\
\text { ASEAN (\% of total exports) }\end{array}$ & CEIC \\
\hline SER & Exports of services to ASEAN (US\$ Million) & CEIC \\
\hline $\mathrm{IM}$ & Imports to ASEAN (\% of total imports) & CEIC \\
\hline FO & $\begin{array}{l}\text { Capital market restriction measure } \\
\text { (KAOPEN index) }\end{array}$ & AREAER \\
\hline FDII & $\begin{array}{l}\text { Foreign direct investment, net inflows } \\
\text { from ASEAN (\% of GDP) }\end{array}$ & WDI \\
\hline FDIO & $\begin{array}{l}\text { Foreign direct investment, net outflows to } \\
\text { ASEAN (\% of GDP) }\end{array}$ & WDI \\
\hline \multicolumn{3}{|c|}{ Control Variables } \\
\hline DPC & Domestic private credit (\% of GDP) & WDI \\
\hline $\mathrm{SCH}$ & Mean years of schooling (years) & CEIC \\
\hline $\mathrm{CPI}$ & Inflation, consumer price index & WDI \\
\hline
\end{tabular}


Ideally, our estimation methodology should be motivated by a particular theoretical framework, even if the estimation is not structural. However, there is no formal theory that incorporates the effects of trade and financial integration in a model of income inequality (Jaumotte et al., 2013). Therefore, our estimation will not be linked directly to any existing theory, but will incorporate key ingredients of the prominent theories in the literature. This study follows closely the approach that of Jaumotte et al. (2013) and Dabla-Norris, Kochlar, Suphaphiphat, Ricka \& Tsounta (2015). In connection with the discussions of the previous section, trade openness and financial integration is combined with an estimation model as follows, where the selected variables are expected to estimate the income inequality in selected ASEAN countries. The empirical analysis is based on the standard panel analysis regression model as follows:

$\ln (G I N I)_{i t}=\alpha_{o}+\alpha_{1}(T O)_{i t}+\alpha_{2}(F O)_{i t}+\delta($ Controls $)+\mu_{t}+\eta_{i}+\varepsilon_{i t}$

Regional integration is divided between various measures of trade openness and financial openness. The subscripts $\mathrm{i}=1, \cdots, \mathrm{N}$ and $\mathrm{t}=1, \cdots, \mathrm{T}$ refer to the cross-section and time series dimensions of the data, respectively. Specifically, to capture the influence of trade integration, 【TO】_it is measured by trade openness to determine how much the economic is expose and rely on international trade. Financial integration, 『FO』_ it on the other hand, is measured by the Chinn-Ito index (2006).

$\ln (G I N I)_{i t}=\alpha_{o}+\alpha_{1} E X_{i t}+\alpha_{2} I M_{i t}+\alpha_{3} F D I I_{i t}+\alpha_{4} F D I O_{i t}+\delta($ Controls $)+\mu_{t}+\eta_{i}+\varepsilon_{i t}$

The de facto measures of trade and financial openness further decompose into subcomponents. Trade openness is replaced by the individual intra export and import shares to GDP, while financial openness is decomposed into inward and outward FDI to examine the channel that contributes towards the widening or narrowing income inequality.

$$
\begin{aligned}
\ln (G I N I)_{i t}= & \alpha_{o}+\alpha_{1} A G R_{i t}+\alpha_{2} M A N U_{i t}+\alpha_{3} S E R_{i t}+\alpha_{4} I M_{i t}+\alpha_{5} F D I I_{i t}+\alpha_{6} F D I O_{i t}+ \\
& \delta(\text { Controls })+\mu_{t}+\eta_{i}+\varepsilon_{i t}
\end{aligned}
$$

To better understand the inequality reducing impact of intra-export, the export to GDP ratio is split by agriculture, manufacturing and services.

The design of this study presents some econometric techniques to investigate the empirical model. Eviews software is used to analyse the data and provide result on the study of relationship between variables. This study explains, panel cointegration, fully modified ordinary least square (FMOLS) and panel VAR Granger causality Wald test. Estimations of all these three methods is conducted so as to incorporate the best fit of estimation. 
INTERNATIONAL JOURNAL OF ACADEMIC RESEARCH IN BUSINESS AND SOCIAL SCIENCES

Vol. 10, No. 2, Feb, 2020, E-ISSN: 2222-6990 @ 2020 HRMARS

\section{Empirical Results}

Panel Cointegration

Table 1: Kao's Residual Cointegration Test Results

\begin{tabular}{lll}
\hline \hline & t-Statistic & Probability \\
\hline ASEAN-8 & & \\
ADF & -2.3293 & $0.0099^{* * *}$ \\
ASEAN-5 & & \\
ADF & 1.3979 & $0.0811^{*}$ \\
ASEAN-3 & & \\
ADF & -1.6933 & $0.0452^{* *}$ \\
\hline \hline
\end{tabular}

Notes: $*, * *, * * *$ denote $10 \%, 5 \%$ and $1 \%$ significant levels, respectively

The panel cointegration approaches suggested by Kao (1999) and Manddala and Wu (1999) will be adopted in this study. Given the number of variables that are adopted in this study, Pedroni (1999) cointegration test will not be suitable because the test is only available for groups containing seven or fewer series. Table 1 reports the result of Kao (1999) cointegration test. The results from the panel cointegration for our model reject the null hypothesis of no cointegration at the $5 \%$ level of significant. Therefore, there is an existence of cointegration between the independent variables and Gini coefficient in the long-run according to Kao's test for the sample of ASEAN-8, ASEAN-5 and ASEAN-3.

\section{Panel Estimation}

Once the cointegration relationship is established, the next step is to estimate the long-run parameters. FMOLS has been proposed to estimate the panel cointegration parameters. The FMOLS methodologies are proposed by Kao and Chiang (2000) to estimate the long- run cointegration vector, for non- stationary panels. Panels FMOLS are methods that are efficient to eliminate the problems of serial correlations and endogeneity. According to Pedroni (2000), group mean tests are preferred over the pooled tests since they allow greater flexibility under the alternative hypothesis. 
INTERNATIONAL JOURNAL OF ACADEMIC RESEARCH IN BUSINESS AND SOCIAL SCIENCES Vol. 10, No. 2, Feb, 2020, E-ISSN: 2222-6990 @ 2020 HRMARS

Table 2: Estimation Results for Income Inequality on ASEAN-8, ASEAN-5 and ASEAN-3 (Dependent Variable: Natural Logarithm of Gini)

\begin{tabular}{|c|c|c|c|}
\hline $\begin{array}{r}\text { Independent } \\
\text { Variables } \\
\end{array}$ & ASEAN-8 & ASEAN-5 & ASEAN-3 \\
\hline \multicolumn{4}{|l|}{ Trade integration } \\
\hline \multicolumn{4}{|l|}{ Export of } \\
\hline \multirow[b]{2}{*}{ Agriculture } & -0.0268 & 0.0035 & -0.2713 \\
\hline & $(-11.5878)^{* * *}$ & $(1.8981)^{*}$ & $(-23.4974)^{* * *}$ \\
\hline \multirow{2}{*}{ Manufacturing } & -0.0883 & -0.1415 & -0.1123 \\
\hline & $(-5.7410)^{* * *}$ & $(-32.9482)^{* * *}$ & $(-4.5774) * * *$ \\
\hline \multirow{2}{*}{ Services } & 0.1321 & -0.0959 & 0.0837 \\
\hline & $(10.8777)^{* * *}$ & $(-3.8274)^{* * *}$ & $(3.1416)^{* * *}$ \\
\hline \multirow{2}{*}{ Import } & 0.1083 & 0.4218 & 0.4981 \\
\hline & $(8.4354)^{* * *}$ & $(8.0490)^{* * *}$ & $(15.3196)^{* * *}$ \\
\hline \multicolumn{4}{|l|}{ Financial integration } \\
\hline \multirow{2}{*}{$\begin{array}{r}\text { Ratio of inward FDI } \\
\text { stock to GDP }\end{array}$} & -0.3409 & -0.0508 & -0.4797 \\
\hline & $(-23.3347)^{* * *}$ & $(-5.6547)^{* * *}$ & $(-20.8944)^{* * *}$ \\
\hline \multirow{2}{*}{$\begin{array}{r}\text { Ratio of outward FDI } \\
\text { stock to GDP }\end{array}$} & 0.0642 & 0.1051 & 0.5002 \\
\hline & $(14.3852)^{* * *}$ & $(50.5468)^{* * *}$ & $(20.6269)^{* * *}$ \\
\hline \multicolumn{4}{|l|}{ Control Variables } \\
\hline \multirow[t]{2}{*}{ Domestic } & -0.2007 & -0.2493 & -0.5629 \\
\hline & $(-17.2593)^{* * *}$ & $(-29.8267)^{* * *}$ & $(-32.5588)^{* * *}$ \\
\hline \multirow[t]{4}{*}{ Average } & -0.0936 & -0.9273 & -0.3779 \\
\hline & $(-1.6629)^{*}$ & $(-48.3138) * * *$ & $(-2.7778)^{* * *}$ \\
\hline & 0.1748 & 0.4603 & -0.1032 \\
\hline & $(1.6630)^{* * *}$ & $(41.6494)^{* * *}$ & $(-2.4511)^{* *}$ \\
\hline
\end{tabular}

Notes: For all the coefficient, the t-statistics are in parenthesis; ${ }^{*}, * *, * * *$ denote $10 \%, 5 \%$ and $1 \%$ significant levels, respectively.

Empirical results based on Table 2 illustrated that ASEAN-8 through the agriculture and manufacturing sector helps to narrow inequality at $1 \%$ significant level. The effect from manufacturing sector imposed a larger magnitude than agriculture sector towards the reduction of inequality. $1 \%$ increase in exporting for manufacturing sector reduce inequality by $0.09 \%$ while agriculture sector by $0.03 \%$. Similarly, $1 \%$ increase from the ratio of inwards FDI stock to GDP is statistically significant in reducing inequality by $0.34 \%$. On the other hand, $1 \%$ increased in ratio of inward FDI stock to GDP improves inequality by $0.34 \%$. 
INTERNATIONAL JOURNAL OF ACADEMIC RESEARCH IN BUSINESS AND SOCIAL SCIENCES Vol. 10, No. 2, Feb, 2020, E-ISSN: 2222-6990 @ 2020 HRMARS

However, when we further decompose the countries into ASEAN-5 and ASEAN-3, different findings are observe through the impact of exporting sector on inequality. Empirical results show that exporting of manufacturing and services sectors were effective in reducing inequality within the ASEAN-5 region. An increase of $1 \%$ export from both manufacturing and services sector reduces inequality by $0.14 \%$ and $0.10 \%$ respectively. However for the sample of ASEAN-3, empirical results postulated that it is export from the agricultural sector that is especially important in reducing inequality, $0.27 \%$ following by manufacturing sector contributing towards $0.11 \%$ and are statistically significant. The ratio of inwards FDI stocks to GDP still remains significant in reducing income inequality in ASEAN-5 and ASEAN-3.

\section{Panel Granger Causality Wald Test}

To analyse the causal relationship between income inequality, trade openness and financial openness, this study adopted the panel data vector autoregressive (PVAR) model that joined the panel data approach with the traditional VAR method developed by Love and Zicchino (2006). Abrigo and Love (2015) expand the suit of routines for the original PVAR developed to include sub-routines to help implement Granger causality tests and optimal moment and model selection. The PVAR routine with Granger causality post estimation helps us to identify the direction of causality between income inequality, trade openness and financial openness.

Table 3: Panel VAR Granger Causality Wald Test Results

\begin{tabular}{|c|c|c|c|}
\hline \multirow{2}{*}{$\begin{array}{l}\text { Dependent } \\
\text { Variables }\end{array}$} & \multicolumn{3}{|c|}{ Sources of Causation (Independent Variables) } \\
\hline & LGINI & LTO & LFO \\
\hline \multicolumn{4}{|l|}{ ASEAN-8 } \\
\hline LGINI & - & $0.3928(0.5309)$ & $0.7700(0.3802)$ \\
\hline LTO & $0.1032(0.7479)$ & - & $0.6289(0.4277)$ \\
\hline LFO & $0.6640(0.4152)$ & $0.2559(0.6130)$ & - \\
\hline \multicolumn{4}{|l|}{ ASEAN-5 } \\
\hline LGINI & - & $2.4496(0.1176)$ & $0.1859(0.6664)$ \\
\hline LTO & $1.2601(0.2615)$ & - & $0.4571(0.4990)$ \\
\hline LFO & $0.7035(0.4016)$ & $1.4936(0.2217)$ & - \\
\hline \multicolumn{4}{|l|}{ ASEAN-3 } \\
\hline LGINI & - & $3.0761(0.0795)^{*}$ & $1.9449(0.1631)$ \\
\hline LTO & $1.0348(0.3090)$ & - & $0.5464(0.4598)$ \\
\hline LFO & $0.2846(0.5937)$ & $0.3195(0.5719)$ & - \\
\hline
\end{tabular}

Notes: Figures denote chi-square statistic values. P-values are in parenthesis. $*, * *, * * *$ denote $10 \%, 5 \%$ and $1 \%$ significant levels, respectively.

Based on the rule of rejection, null hypothesis is rejected when p-value is smaller than the significant value. As shown in Table 3, there is no evidence of causality from trade and financial openness towards Gini coefficient in ASEAN-8 and ASEAN-5 but otherwise for ASEAN-3. In accordance with these results, Gini coefficient in ASEAN-3 will be influence by trade openness in the short run. 
INTERNATIONAL JOURNAL OF ACADEMIC RESEARCH IN BUSINESS AND SOCIAL SCIENCES Vol. 10, No. 2, Feb, 2020, E-ISSN: 2222-6990 @ 2020 HRMARS

\section{Discussion and Conclusion}

The deepening of trade and financial integration across the region has become an issue of great importance. Hence, this study attempts to add empirical evidence to the impact of regional integration on income inequality. We first examined the existence of long-run relationship between the variables in selected ASEAN countries from 2005 to 2018 then analyzed its potential determinants. Using panel series data, we applied the Kao (1999) cointegration test to identify the existence of long-run relationship and fully-modified ordinary least square to analyze the relationship between income inequality, trade integration and financial integration. The finding is consistent with the link between trade openness and income distribution that is implied by the Heckscher-Ohlin model and the Stopler-Samuelson theorem. Overall, the regression analysis showed that the trade integration impose a larger magnitude in reducing inequality than financial integration. One of the main finding is that the effects of regional integration are contrasting between ASEAN-5 and ASEAN3. Thus, integration policies should not be universally implies on countries with diverse economics structural and development activities.

The findings showed that ASEAN-5 could narrow inequality by engaging in manufacturing and servicing exporting activities. The global manufacturing hub has expanded quickly in terms of valueadded and employment, being one of the ASEAN's key economic growth drivers (Gnanasagaran, 2018). Economic integration and a more coordinated and liberalised policy environment enable the region to low operation and transaction costs had also attracted businesses from larger manufacturing bases (Ministry of International Trade and Industry [MITI], 2015). Further reforms to open up trade in services would in turn boost economic activity and improve inequality. Similarly, Warr (2002) found that the service sectors in Indonesia, Thailand, Malaysia and the Philippines imposed the greatest reduction on poverty and further improved income inequality in an economy. In terms of sectoral disaggregates, the exports of the service industry are dominated by three sectors: travel, transport and other business services.

Conversely, the empirical findings showed that agriculture and manufacturing sector significantly reduce inequality for ASEAN-3. Notably, agriculture is still the backbone of these economies supporting a large population and sustaining rural viability. The agriculture sector has a higher possibility of reduce inequality than other sectors as most of the poor people live in rural areas and the majority of them are still depending on agriculture for a living (Tomich et al., 2019). The unskilled worker will be absorbed into agriculture while skilled worker into the manufacturing sector when engaged in regional trade. Hence agriculture sector remains an important sector to keep employment and gradually narrow the income distribution against the urban population (Rillo \& Sombilla, 2015). CLMV countries started their industrialization process through digitalization with low-value-added and labour-intensive industries that would exhibit the highest increasing returns at the first stage of development (Magacho \& McCombie, 2017). In later stages, when the rate of return increased, it becomes more advantages to expand the production towards capital and technology-intensive industries.

Financial integration through the increased in FDI inflows help to narrow income inequality among the ASEAN-8 countries. FDI inflows helped inequality reduction by increasing economic and social 
welfare. Capital inflows into productive firms levied great welfare and increased productivity in the sector that employed a huge amount of labour. The increase of labour demand in productive industry creates job opportunities for the local, allowing them to move between industry to seek for better paying jobs and reducing unemployment. The largest recipient sectors were manufacturing, financial and insurance activities and real estate activities. However, the benefits gained varied according to the development of human capital.

Financial reform policies aim at expanding financial access and depth, as well as enhancing financial efficiency and stability should encourage. These policies may include relaxing credit and interest controls, and improving banking and securities market supervision, especially among the lower income cohort and rural population. Financial sector policy reforms should provide poor segments with better access to financial services through establishing microfinance institution or cooperative banks rather than fully-fledged commercial banks. This allows the poor to borrow against their assets, make productive investment and alleviate poverty over time. It is also important to develop an effective regulatory system for financial institutions and to enhance financial infrastructure to limit the risk taking of banks. Hence, it is essentially important to consider policies that can promote financial development in countries with wider inequality and concentrated poverty.

The government also plays an important role in dealing with the widening of the income distribution. If a government plans to improve the distribution of income, it is suggested that government policymakers focus on education policies that promote educational expansion while affording individuals equal and greater access to educational opportunities. Improving education quality, eliminate financial barriers to higher education helps to determine the occupational choice, access to jobs, the level of pay and play a pivotal role as a signal of ability and productivity in the job market. Education policies focusing on equity in education may be a particularly effective way for countries to increase earning mobility between the generations and reduce income inequality over time. Countries can work towards this goal by giving equal opportunities to both disadvantage and advantage students to achieve strong academic outcomes, laying a pathway for them to continue a higher level of education and eventually secure good jobs.

\section{References}

Ametoglo, M., \& Guo, P. (2016). Regional economic integration and income inequality in Latin America: The case of Andean Community of Nations. Journal of Economics and Sustainable Development, 7(14), 176-185.

Ando, M., \& Kimura, F. (2014). Evolution of machinery production networks: Linkage of North America with East Asia. Asian Economic Papers, 13(3), 121-160.

Asian Development Bank (ADB). (2018, April 11). Continued reforms key to Myanmar's economic growth. Retrieved from https://www.adb.org/news/continued-reforms-key-myanmarseconomic-growth

Asteriou, D., Dimelis, S., \& Moudatsou, A. (2014). Globalization and income inequality: A panel data econometric approach for the EU27 countries. Economic Modelling, 36, 592-599.

Auguste, D. (2012). European integration and income inequality convergence. Retrieved from https://paa2013.princeton.edu/papers/132193 
INTERNATIONAL JOURNAL OF ACADEMIC RESEARCH IN BUSINESS AND SOCIAL SCIENCES Vol. 10, No. 2, Feb, 2020, E-ISSN: 2222-6990 @ 2020 HRMARS

Baek, I., \& Shi, Q. (2016). Impact of economic globalization on income inequality: Developed economies vs emerging economies. Global Economy Journal, 16(1), 49-61.

Barro, R. J. (2000). Inequality and growth in a panel of countries. Journal of Economic Growth, 5(1), 5-32.

Calderón, C., \& Chong, A. (2001). External sector and income inequality in interdependent economies using a dynamic panel data approach. Economics Letters, 71(2), 225-231.

Chen, C. (2016). The impact of foreign direct investment in urban-rural inequality: Evidence from China. China Agriculture Economic Review, 8(3), 480-497.

Chen, C., Zhao, H., \& Zhou, Y. (2017). Foreign direct investment and wage inequality, Evidence from the People's Republic of China. Asian Development Bank Institute. Retrieved from https://pdfs.semanticscholar.org/3671/0ed680861341ebc391e33028269e0c3ba03d.pdf

Chintrakarn, P., Herzer, D., \& Nunnenkamp, P. (2011). FDI and income inequality: Evidence from a panel of U.S. States. Economic Inquiry, 50(3), 788-801.

Cornia, G. A. (2011). Economic integration, inequality and growth: Latin America vs the European economies in transition. United Nations. Retrieved from https://www.un.org/esa/desa/papers/2011/wp101_2011.pdf

Delios, A. (2017). Commentary: Is ASEAN's economic integration still a work in progress? Channel News Asia. Retrieved from https://www.channelnewsasia.com/news/asia/commentary-isasean-s-economic-integration-still-a-work-in-8814696

Figini, P., \& Görg, H. (2011). Does foreign direct investment affect wage inequality? An empirical investigation. The World Economy, 34(9), 1455-1475.

Furuoka, F., Rasiah, R., Idris, R., Ziegenhain, P., Jacob, R. I., \& Munir, Q. (2018). Income convergence in the ASEAN-5 countries. International Journal of Business and Society, 19(3), 554-569.

Gnanasagaran, A. (2018). Driving growth in ASEAN economies. The ASEAN Post. Retrieved from https://theaseanpost.com/article/driving-growth-asean-economies

Gourdon, J., Maystre, N., \& De Melo, J. (2007). Openness, inequality, and poverty: Endowments matter. World Bank.

Hartley, K. (2017). Inequality looms beneath the shiny façade of Southeast Asia's growth. Channel News Asia. Retrieved from https://www.channelnewsasia.com/ news/asia/commentary-inequality-looms-beneath-the-shiny-facade-of-8743726

Herzer, D., Hühne, P., \& Nunnenkamp, P. (2014). FDI and income inequality- Evidence from Latin American economies. Review of Development Economics, 18(4), 778-793.

Hew, D. (2006). Economic integration in East Asia: An ASEAN perspective. UNISCI Discussion Papers. Retrieved from https://www.ucm.es/data/cont/media/www/pag-72530/UNISCI11Hew.pdf

Ibrahim, M. (2015). ASEAN financial integration- Outlook and implications. Bank Negara Malaysia. Retrieved from http://www.bnm.gov.my/ index.php?ch=en_speech\&pg=en_speech\&ac=556\&lang=en

Krumm, K., \& Kharas, H. (2004). East Asia integrates: A trade policy agenda for shared growth. World Bank. Retrieved from http://documents.worldbank.org/curated/en/ 759971468748770496/East-Asia-integrates-a-trade-policy-agenda-for-shared-growth

Kuo, K. H., \& Lee, C. T. (2017). Economic integration, growth and income distribution. Australian Economic Papers, 56(1), 59-71. 
INTERNATIONAL JOURNAL OF ACADEMIC RESEARCH IN BUSINESS AND SOCIAL SCIENCES Vol. 10, No. 2, Feb, 2020, E-ISSN: 2222-6990 ¿ 2020 HRMARS

Lim, G. C., \& McNelis, P. D. (2013). Alternative government spending rules: Effects on income inequality and welfare. Macroeconomic Dynamics, 17(7), 1496-1518.

Macdonald, K., Marshall, S., \& Pinto, S. (2012). New visions for market governance. London: Routledge.

Magacho, G. R., \& McCombie, J. S. (2017). A sectoral explanation of per capita income convergence and divergence: estimating Verdoorn's law for countries at different stages of development. Cambridge Journal of Economics, 42(4), 917-934.

Mahesh, M. (2016). The effects of trade openness on income inequality- Evidence from BRIC countries. Economics Bulletin, 36(3), 1751-1761.

Meschi, E., \& Vivarelli, M. (2009). Trade openness and income inequality in developing countries. World Development, 37(2), 287-302.

Mihaylova, S. (2015). Foreign direct investment and income inequality in Central and Eastern Europe. Theoretical and Applied Economics, 22(2), 23-42.

Milanovic, B. (2002). True world income distribution, 1988 and 1993. First calculation based on household surveys alone. The Economic Journal, 112(476), 51-92.

Milanovic, B. (2005). Can we discern the effect of globalization on income Distribution? Evidence from household surveys. The World Bank Economic Review, 19(1), 21-44.

Ministry of International Trade and Industry (MITI). (2015). Measure to address impact of global economic slowdown on Malaysia's trade and industry. Retrieved from https://www.miti.gov.my/index.php/pages/view/2387

Mordecai, A. (2017). What is the future of integration and inequality in ASEAN? The Diplomat. Retrieved from https://thediplomat.com/2017/09/what-is-the-future-of-integration-andinequality-in-asean/

Mugeni, S. (2015). Foreign Investment, Democracy and Income Inequality: Empirical Evidence.

Pham, T. H. H. (2014). Intra-regional trade and income inequality: Where do we stand? HAL. Retrieved from https://hal.archives-ouvertes.fr/hal-01087366/document

Raychaudhuri, A., \& De, P. (2016). Trade, infrastructure and income inequality in selected Asian countries: An empirical analysis. New Delhi: Springer.

Rillo, A. D., \& Sombilla, M. A. (2015). Enhancing agriculture productivity in CLMV countries: Challenges and agenda for reforms. Asian Development Bank Institute. Retrieved from https://www.adb.org/sites/default/files/publication/172920/adbi-wp542.pdf

Roser, M., \& Cuaresma, J. C. (2016). Why is income inequality increasing in the developed world? Review of Income and Wealth, 62(1), 1-27.

Salman, Z., \& Javed, M. (2011). The impact of trade liberalisation on wage inequality: Case of Pakistan. The Pakistan Development Review, 50(4), 575-594.

Samuelson, P. A. (1948). International trade and the equalisation of factor prices. The Economic Journal, 58(230), 163-184.

Selvarajan, S. K., Ab-Rahim, R., \& Md-Nor, N. G. (2018). Trade and investment convergence clubs in East Asia Pacific. Institutions and Economies, 10(4), 91-108.

Sovachana, P. (2013). The challenges of the CLMV countries and the role of development partner. ASEAN Center. Retrieved from http://www.aseancenter.org.tw/ upload/files/outlook008-05.pdf 
INTERNATIONAL JOURNAL OF ACADEMIC RESEARCH IN BUSINESS AND SOCIAL SCIENCES Vol. 10, No. 2, Feb, 2020, E-ISSN: 2222-6990 @ 2020 HRMARS

Stolper, W. F., \& Samuelson, P. A. (1941). Protection and real wages. The Review of Economic Studies, 9(1), 58-73.

Suanes, M. (2016). Foreign direct investment and income inequality in Latin American: A sectoral analysis. Cepal Review, 45-61.

Tee, H. G., Kaliappan, S. R., Lee, C., \& Said, R. (2017). Trade openness and income inequality in selected developing countries. Global Conference on Business and Economics Research (GCBER) 2017. Retrieved from http://www.econ.upm.edu.my/content/trade_openness_and_income_inequality_in_selec ted_developing_countries-32947

Teh, B. C. G. (2004). ASEAN's regional integration challenge: The ASEAN process. The Copenhagen Journal of Asian Studies, 20, 70-94.

Tomich, T. P., Lidder, P., Coley, M., Gollin, D., Meinzen-Dick, R., Webb, P., \& Carberry, P. (2019). Food and agricultural innovation pathways for prosperity. Agricultural Systems, 172, 1-15.

Trinh, N. H. (2016). The effect of foreign direct investment on income inequality in Vietnam. International Journal of Economics, Commerce and Management, 4(12), 158-173.

Ucal, M., Haug, A. A., \& Bilgin, M. H. (2016). Income inequality and FDI: Evidence with Turkish data. Applied Economics, 48(11), 1030-1045.

Vinayak, H. V., Thompson, F., \& Tonby, O. (2014). Understanding ASEAN: Seven things you need to know. McKinsey \& Company. Retrieved from https://www.mckinsey.com/ industries/public-sector/our-insights/understanding-asean-seven-things-you-need-toknow

Warr, P. (2002). Poverty reduction and sectoral growth: Evidence from Southeast Asia. Paper presented at the WIDER Development Conference on Growth and Poverty, Helsinki.

World Bank. (2019). Malaysia Home: Overview. Retrieved from http://www.worldbank.org/en/country/malaysia/overview

Yenipazarli, A., \& Kucukkaya, H. (2016). Does the impact of trade openness on income and income inequality differ in developed and developing countries? Eurasian Studies in Business and Economics, 2(3/2), 479-489.

Zakaria, M., \& Fida, B. A. (2016). Trade openness and income inequality in China and the SAARC region. Asian-Pacific Economic Literature, 30(2), 33-44. 